\title{
Approaches to large-class teaching
}

BOOK TITLE:

Large-class pedagogy: Interdisciplinary perspectives for quality higher education

\section{BOOK COVER:}

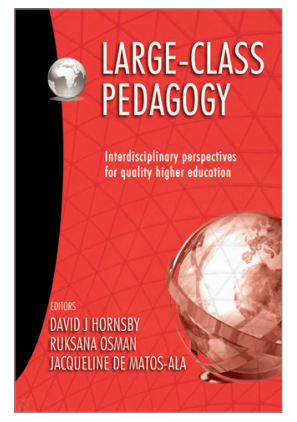

\section{EDITORS:}

David J Hornsby, Ruksana Osman, Jaqueline de Matos-Ala

\section{ISBN:}

9780987009647

PUBLISHER:

SUN Press, Stellenbosch, ZAR225

\section{PUBLISHED:}

2013

\section{REVIEW TITLE:}

Approaches to largeclass teaching

\section{REVIEWER:}

Chrissie Boughey

EMAIL:

C.Boughey@ru.ac.za

\section{AFFILIATION:}

Academic and Student Affairs, Rhodes University, Grahamstown, South Africa

\section{POSTAL ADDRESS:}

Office of the DVC, Academic and Student Affairs, Rhodes University, PO Box 94, Grahamstown 6140, South Africa

\section{HOW TO CITE:}

Boughey C. Approaches to large-class teaching. S Afr J Sci. 2015;111(1/2), Art. \#a0094, 2 pages. http://dx.doi. org/10.17159/sajs.2015/a0094

\section{(C) 2015. The Author(s).} Published under a Creative Commons Attribution Licence.
As the late Wally Morrow ${ }^{1}$ long ago pointed out, in South Africa the shift to a more equitable political dispensation would mean that academic teachers needed to think hard about their need to teach large classes in spite of dominant discourses which said 'small is best'. More than 20 years on, 'small is best' thinking continues to dominate South African higher education in spite of the fact that the system has almost doubled in size since the early 1990s and, if targets in the National Development Plan $2030^{2}$ are reached, will swell even further in the next 15 years. Moreover, this growth will take place in the context of a shortage of academics, as many of the existing cohort move into retirement and new recruits to the profession are hard to find. In addition, given dominant neoliberal philosophies and the current economic climate, this growth probably will have to take place with no increase in funding for higher education in real terms. In this context, the publication of a book written by practising South African academics on large-class teaching is particularly welcome.

The editors of the book, David Hornsby, Ruksana Osman and Jacqueline de Matos-Ala - all from the University of the Witwatersrand - introduce the volume by arguing that management of the learning environment in large classes can result in better quality student learning. They, along with other authors in the volume, then draw on theory related to learning styles, most notably work on 'deep' and 'surface' approaches to learning, to make this argument.

The original work on 'deep' and 'surface' approaches to learning ${ }^{3,4}$ established that the way students perceived the contexts in which they were studying led to the adoption of approaches to learning that were understood to bring the greatest reward (typically higher marks). This has then led to claims that manipulation of the learning environment, particularly in the direction of what Biggs ${ }^{5}$ terms 'constructive alignment', can result in shifts in students' approaches to learning and, thus, better quality learning outcomes.

In spite of the popularity of such claims, their validity is undecided; although a large-scale review ${ }^{6}$ of extant work, led by Frank Coffield of the London Institute of Education, found little good evidence to support them. As Haggis ${ }^{7}$ also points out, the model of a 'deep' approach to learning, understood to be achievable through the manipulation of classroom contexts, actually describes the very sophisticated ways academics go about learning - ways that have taken many years, not a single course, to develop.

Of greater concern, however, is the phenomenon identified by Haggis ${ }^{7}$ that sees the original construct of approaches to learning shifted into types of learning and even types of learner as work in this area has progressed. It is into this trap that some authors in the book fall, at least as far as identifying 'deep' and 'surface' learning. While semantic shifts of this nature are easily dismissed, their significance in South Africa is not to be underestimated. In moving away from an understanding of the way context shapes perceptions, and thus learning approaches, to the more fixed constructs of types of learning and learners, work on learning styles not only produces individualised, asocial and acultural concepts of learning but also, as Reynolds ${ }^{8}$ points out in a trenchant critique of work on learning styles, 'obscures the social bases of difference in the way people approach learning'.

This critique of the use of theory on learning styles by no means undermines the usefulness of this book. The central section of the volume is devoted to a series of case studies of large-class teaching and learning in action. These are extremely valuable for anyone faced with the need to teach a large class regardless of the years of experience they may bring to the task. Brenner's chapter on the use of interactive classroom technology (or 'clickers') is particularly valuable, especially given the way the use of the technology is supported by social constructivist learning theory. Examples of questions used in an actual course show how the lecturer can move away from a focus on the dissemination of content knowledge to an interactive engagement with students that supports them as they make connections and engage in levels of thinking beyond merely trying to remember.

Also extremely valuable is Brenner and Nichols' account of the use of writing to promote critical thinking in large classes. The quality of students' writing is a perennial complaint in any university, which often is addressed, in South Africa at least, by stand-alone writing courses. Brenner and Nichols offer a very different solution, much more strongly supported by theory, in the form of Writing across the Curriculum, Writing in the Discipline and Writing Intensive approaches involving the use of writing as a tool for learning. Problems with introducing these approaches in South Africa are numerous and relate to lecturers' reluctance to see themselves as able to contribute to students' writing development alongside a fear, particularly in relation to Writing Intensive approaches, that any intervention on their part will result in even more work. The solution proposed by Brenner and Nichols involves reconstructing work on writing as 'Critical Engagement through Writing' - an approach which can 'successfully engage all students and help them to develop the necessary skills to learn to enquire, think together and learn to learn' (p.98). The validity of writing as a tool for learning has been established as a result of a long vein of research going back to the work of Janet Emig ${ }^{9}$ in the 1970s. Brenner and Nichols draw on this work to explore the way writing can be used as a tool for learning in a large class. The practical examples provide real clarity on the way this sort of approach could be implemented elsewhere; these examples, coupled with the soundness of the approach itself, make the chapter essential reading for any academic daunted by the thought of reading through yet another pile of poorly written student scripts.

Brenner and Nichols' chapter emphasises the importance of support for lecturers attempting to engage with the challenges of teaching a large class - in this case support which includes the availability of tutors and expertise from individuals knowledgeable about writing. Elsewhere in the book, other kinds of support are indicated. Butcher and Hoosen's contribution - on the use of open educational resources to support learning in large classes - indicates the need for the technical expertise necessary to sustain the use of information and communication technologies. Similarly, Hornsby and de Matos-Ala describe a wide range of strategies used to promote student engagement in 
a large class, noting the importance of a 'state of the art lecture theatre' without which 'it would be difficult to recreate this dynamic teaching environment'. They go on to argue that 'a well-equipped venue is a prerequisite for interactive large class teaching' (p.85).

Statements such as this might well elicit a sense of despondency from those who work on campuses without such support and infrastructure. However, there is sufficient in the book to provide ideas and practical solutions regardless of context. If anyone in South African higher education is looking to begin reading on teaching, this volume is an excellent place to start.

\section{References}

1. Morrow W. Epistemological access in the university. AD Issues. 1993;1:3-4.

2. National Planning Commission, Office of the Presidency. National Development Plan: Vision for 2030. Pretoria: Office of the Presidency; 2014.
3. Marton F, Saljo R. Approaches to learning. In: Marton F, Hounsell D, Entwistle N, editors. The experience of learning. Edinburgh: Scottish Academic Press; 1993.

4. Marton F, Beaty E, Dall 'Alba G. Conceptions of learning. Int J Educ Res. 1993;19(3):277-300.

5. Biggs J. Enhancing teaching through constructive alignment. High Educ. 1996;32(3):347-364. http://dx.doi.org/10.1007/BF00138871

6. Coffield F, Mosely D, Hall E, Ecclestone K. Learning styles and pedagogy in post-16 learning: A systematic and critical review. London: Learning Skills and Research Centre; 2004.

7. Haggis T. Constructing images of ourselves? A critical investigation into approaches to learning research. Br Educ Res J. 2003;29(1):89-104. http:// dx.doi.org/10.1080/0141192032000057401

8. Reynolds M. Learning styles: A critique. Manage Learn. 1997;28(2):115133. http://dx.doi.org/10.1177/1350507697282002

9. Emig J. Writing as a mode of learning. Coll Compos Commun. 1977;28(2):122128. http://dx.doi.org/10.2307/356095 